\title{
Correction to: Boundary layer perspective assessment of air pollution status in Wuhan city from 2013 to 2017
}

\author{
Yassin Mbululo $\mathbb{D} \cdot$ Jun Qin • Zhengxuan Yuan • \\ Fatuma Nyihirani $\cdot$ Xiang Zheng
}

Published online: 20 February 2019

(C) Springer Nature Switzerland AG 2019

\section{Correction to: Environ Monit Assess (February 2019) 191:69 \\ https://doi.org/10.1007/s10661-019-7206-9}

The original version of this article unfortunately contained an error in the Figure 2 caption.

The corrected Figure 2 caption is shown below.

Fig. 2 Vertical structure of the atmosphere on (a) 27-112013, $\mathrm{PM}_{2.5}=64.6 \mu \mathrm{g} / \mathrm{m}^{3}$ and $\mathrm{AQI}=87$ (b) $28-11-2013$, $\mathrm{PM}_{2.5}=46.2 \mu \mathrm{g} / \mathrm{m}^{3}$ and $\mathrm{AQI}=73$ (c) 29-01-2013, $\mathrm{PM}_{2.5}$ $=61.4 \mu \mathrm{g} / \mathrm{m}^{3}$ and $\mathrm{AQI}=92$ (d) $30-11-2013, \mathrm{PM}_{2.5}=110.2$ $\mu \mathrm{g} / \mathrm{m}^{3}$ and $\mathrm{AQI}=144$ (e) $01-12-2013, \mathrm{PM}_{2.5}=137.4 \mu \mathrm{g} /$ $\mathrm{m}^{3}$ and $\mathrm{AQI}=182$ (f) $02-12-2013, \mathrm{PM}_{2.5}=134.6 \mu \mathrm{g} / \mathrm{m}^{3}$

The online version of the original article can be found at https://doi.org/10.1007/s10661-019-7206-9

Y. Mbululo $\cdot$ J. Qin $(\bowtie) \cdot$ Z. Yuan $\cdot$ F. Nyihirani $\cdot$ X. Zheng

School of Environmental Studies, China University of Geosciences, 388 Lu Mo Road, Wuhan 430074, China e-mail: qinjun@cug.edu.cn

Y. Mbululo

Department of Geography and Environmental Studies, Solomon Mahlangu College of Science and Education, Sokoine University of Agriculture, Morogoro, Tanzania

F. Nyihirani

Centre for Environment, Poverty and Sustainable Development, Mzumbe University, Morogoro, Tanzania and AQI $=178(\mathrm{~g})$ 03-12-2013, $\mathrm{PM}_{2.5}=178 \mu \mathrm{g} / \mathrm{m}^{3}$ and $\mathrm{AQI}=228$ (h) $04-12-2013, \mathrm{PM}_{2.5}=293 \mu \mathrm{g} / \mathrm{m}^{3}$ and AQI= 343 (i) $05-12-2013, \mathrm{PM}_{2.5}=248 \mu \mathrm{g} / \mathrm{m}^{3}$ and AQI $=298$ (j) 06-12-2013, $\mathrm{PM}_{2.5}=252 \mu \mathrm{g} / \mathrm{m}^{3}$ and AQI $=330(\mathrm{k})$ 07-122013, $\mathrm{PM}_{2.5}=312 \mu \mathrm{g} / \mathrm{m}^{3}$ and AQI $=362$ (l) 09-12-2013, $\mathrm{PM}_{2.5}=115 \mu \mathrm{g} / \mathrm{m}^{3}$ and $\mathrm{AQI}=150$ showing the profile of Temperature (red line, ${ }^{\circ} \mathrm{C}$ ), relative humidity (green line, $\%$ ), wind velocity (blue line, $\mathrm{m} / \mathrm{s}$ ), and dominant wind direction (grey line) during the pollution process. The number on $\mathrm{X}$-axis is the result after dividing the relative humidity value by 10 and the wind direction angle by 30 , while temperature and wind speed remain the same

Publisher's note Springer Nature remains neutral with regard to jurisdictional claims in published maps and institutional affiliations. 